\title{
THE RESEARCH OF CIRCULATION WATER SUPPLY SYSTEM OF POWER UNIT OF THERMAL POWER PLANT WITH HELLER COOLING TOWER
}

\author{
Lviv Polytechnic National University, \\ ${ }^{I}$ Department of Hydraulic and Water Engineering, \\ mykola.p.bosak@lpnu.ua \\ ${ }^{2}$ Private Company "LVIVORGRES"
}

(C) Bosak M., Hvozdetskyi O., Pitsyshyn B., Vdovychuk S., 2020

\begin{abstract}
Analytical hydraulic researches of the circulating water cooling system of the power unit of a thermal power plant with Heller cooling tower have been performed. Analytical studies were performed on the basis of experimental data obtained during the start-up tests of the circulating water cooling system of the "Hrazdan-5" power unit with a capacity of 300 MW. Studies of the circulating water cooling system were carried out at an electric power of the power unit of 200-299 MW, with a thermal load of 320-396 Gcal/hr. By circulating pumps (CP), water mixed with condensate is fed to the cooling tower, from where it is returned through the turbine for spraying by nozzles in the turbine steam condenser. An attempt to increase the water supply to the condenser by increasing the size of the nozzles did not give the expected results. The amount of the water supply to the circulating pumping station depends on the pressure loss in the circulating water cooling system. The highest pressure losses are in hydro turbines (HT), which are part of the circulating pumping station. Therefore, by adjusting the load of the hydro turbine, with a decrease in water pressure losses, you can increase the water supply by circulating pumps to the condenser. Experimental data and theoretical dependences were used to calculate the changed hydraulic characteristics of the circulating water cooling system. As a result of reducing the pressure losses in the section of the hydro turbine from 1.04 to $0.15 \mathrm{kgf} / \mathrm{cm}^{2}$, the dictating point for the pressure of circulating pumping station will be the turbine steam condenser. The thermal power plant cooling tower is designed to service two power units. Activation of the peak cooler sectors of the cooling tower gives a reduction of the cooled water temperature by $2-4{ }^{\circ} \mathrm{C}$ only with the spraying system.

Key words: circulating water cooling system, water pressure losses, flow rate and head pressure of circulating pumps, Heller cooling tower.
\end{abstract}

\section{Introduction}

Steam condensing systems for turbines of power units and cooling of circulating water are important components of thermal power plants. The relevance of the research is related to the restrictions in many regions of water consumption for technical needs. Another important factor is also the significant payment of power plants for the amount of water consumed. This encourages the use of closed circulating water cooling system of thermal power plants, with mixing steam condensers. As the vapor pressure in such condensers is higher, it partially reduces the power of the turbo generator of the power unit. Therefore, it is important to supply as much cooling water as possible. In general, the actual hydraulic and temperature characteristics of such steam condensing and circulating water cooling systems may differ slightly from the design ones. Therefore, clarification of the actual characteristics of the circulating water cooling system during the start-up tests of the power unit and analysis of their results is important for further operation. 
Circulating water cooling systems for thermal power plants in dry cooling towers are widely used in various regions and countries around the world. This is due to both the trend of water conservation and the lack of water supply sources for use in open circulating water cooling system with wet cooling towers or a cooling reservoir. Scientific sources contain relevant publications on the technical characteristics and prospects for the use of such technical water supply systems.

A scientific article (M. Deziani et al., 2017; A.R. Seifi et al., 2018) deals with the problem of reducing water losses due to evaporation in a cooling tower of a power plant. For this purpose, a laboratory model of wet cooling of circulating water in a cooling tower with an additional air heat exchanger and an auxiliary fan was investigated. As a result, evaporation water losses are expected to be reduced by $35 \%$.

In the paper (A. Kheneslu et al., 2020; G. Yang et. al., 2020) on the basis of operational data (change in temperature, atmospheric air pressure, transverse wind direction, vacuum pressure of the condenser) the influence of Heller cooling tower on the power of thermal power plant was estimated. It has been found that the effect of wind on the operation of cooling tower is greater than the change in atmospheric pressure. Similar processes of transverse wind influence have been studied for cooling towers with natural air draft and dry cooling (Dong et al., 2019; W. Ge et al., 2020).

In research paper (Nourani et al., 2019) performed temperature and economic evaluation of hybrid cooling towers. The results show that using hybrid cooling towers, water consumption for the power plant cooling system is reduced by $34 \%$.

The paper (Jahangiri et al., 2019) presents a feasibility study of the use of flue gases from a power plant in the Heller cooling tower to improve its performance. As a result, during wind conditions the capacity increased by $7.92 \mathrm{MW}$ due to the decrease in the temperature of the cooling water and the steam pressure in the condenser.

In the paper (Dong et al., 2019) investigated a new method for predicting the transition time of start of dry cooling towers in the absence of inflow of cold air. The time required to start the cooling tower with certain operating parameters increases with increasing height of the cooling tower, but decreases with increasing difference between air temperature and temperature of heat exchanger.

In the paper (Li et al., 2017; X. Chen et al. 2019; Z. Dang et al. 2019) it was found that the transverse wind negatively affects natural draft for a low dry cooling tower of the circulation water of a thermal power plant. If the velocity of transverse wind is higher than critical, then the natural draft of the air in the cooling tower and water cooling decreases.

The paper (Dong et al., 2018) presents a one-dimensional model of transitional cooling towers, which can be used to simulate the process of starting a natural draft in cooling towers with dry cooling. The transient process of starting natural cooling towers at thermal power plants for three different inlet temperatures has been studied. It is argued that the higher the inlet air temperature, the greater its velocity and therefore the shorter the process of starting the cooling tower.

The analyzed scientific works provide valuable technical information on the study of dry cooling of circulating water of thermal power plants in cooling towers. The choice of the topic of hydraulic research of the circulating water cooling system with Heller cooling towers is due to the fact that this system is closed with technological elements of excess and vacuum water pressure and the need to clarify the influence of mode of operation of the cooling tower and hydro turbine on flow rate of circulating pumping station. The feature of the research is that they relate to the operation of circulating water cooling system located in areas with low atmospheric pressure.

\section{The purpose of the study}

The main purpose of the work is to clarify the hydraulic regime of the circulating water cooling system with a dry cooling tower of the power unit of thermal power plant in order to increase the water supply by circulating pumps. 
Research objectives:

- analysis of the pressure losses of circulating pumps along the system path from the turbine steam condensers to the cooling sectors of the cooling tower.

- take into account the actual hydrothermal parameters of the steam condensation system and the turbine condensate cooling system for various heat loads from the power unit.

\section{Materials and methods}

The system of steam condensation and cooling of circulating water of the "Hrazdan-5" power unit with steam turbine type K 300-24-3 includes: water pipelines, Heller dry cooling tower, mixing type condenser, circulating pumps (Fig. 1). Condensate with circulating water is supplied to the cooling tower for cooling by circulation pumps. The diameter of the main water pipelines is $2.0 \mathrm{~m}$, the water velocity in this pipelines is $1.6-2.2 \mathrm{~m} / \mathrm{s}$. From the cooling tower, water flows through the turbines to the mixing condenser with 4640 spray nozzles with a diameter of 13.0 and $15.0 \mathrm{~mm}$. The cooling tower cools the circulating water coming from the two power units. Circulation of cooling water is provided by circulating pumps - two pumps of type Д 12500-24 and two pumps of type Д 6300-27.

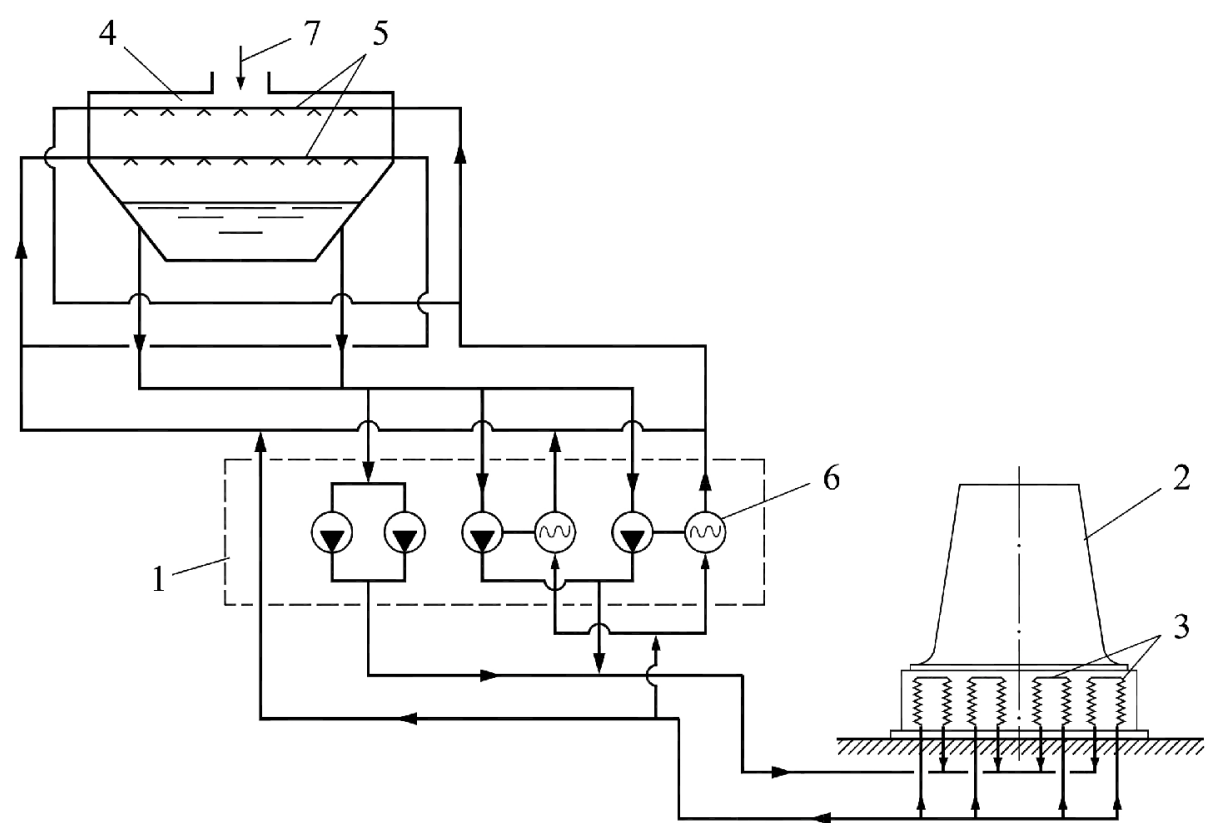

Fig. 1. Schematic diagram of cooling of circulating water of thermal power plant with dry cooling tower: 1 - circulating pump station; 2 -dry cooling tower; 3 - main cooling sectors; 4 - mixed type condenser; 5 - distribution pipeline with spray nozzles; 6 - hydro turbine; 7 - steam from the turbine

Six main and three peak heat exchange cooling sectors of the cooling tower are arranged for one power unit. The sectors consist of 190 cooling deltas $20 \mathrm{~m}$ high and 2 cooling deltas $15 \mathrm{~m}$ high.

Tests of the cooling tower circulating water cooling system were carried out in accordance with the requirements of the methods (Tipovaya metodika ispyitaniy gradiren i ohladitelnyih bashen" MT 701000088-86, 1986; Metodicheskie ukazaniya po ispyitaniyu tsirkulyatsionnyih nasosov i sistem tsirkulyatsionnogo vodosnabzheniya paroturbinnyih ustanovok elektrostantsiy" MU 34-70-002-82, 1986). During the tests were measured:

- flow rate of circulating water and temperature of circulating water at the inlet and outlet of the cooling tower;

- water pressure at the inlet and outlet of the system elements;

- temperature and humidity of atmospheric air, barometric pressure and wind flow speed. 
To measure these indicators were used the following devices: digital thermometer ТО-Ц024-10; anemometer "Testo 410"; ultrasonic flowmeter "GE Panametriks"; manometers of accuracy class 0.6; certified standard operational control devices.

\section{Results and discussion}

As a basis for analytical studies of the hydraulic characteristics of the circulating water cooling system, the results of the characteristics of the system at the stage of start-up tests were taken. The thermal load on the condenser and the cooling tower was 320-396 Gcal $/ \mathrm{hr}$. The flow rate of circulating water with condensate was in the range of $25000-30000 \mathrm{~m}^{3} / \mathrm{hr}$, depending on the heat load and air temperature. The maximum supply of circulating water was $85 \%$ of the design $\left(36000 \mathrm{~m}^{3} / \mathrm{hr}\right)$.

The process of water cooling was carried out on 8-12 main cooling sectors of the cooling tower. At a maximum heat load of $396 \mathrm{Gcal} / \mathrm{hr}$ and an air temperature of $13.2^{\circ} \mathrm{C}$, the temperature of the cooled water was $6.0^{\circ} \mathrm{C}$ lower than the normative one (because the cooling tower was receiving load from only one power unit for all twelve cooling sectors). The temperature of the mixture of condensate and cooled circulating water in the cooling tower varied from $9.5^{\circ} \mathrm{C}$ to $14.15^{\circ} \mathrm{C}$. Activation of the peak cooler sectors of the cooling tower gives a reduction of the cooled water temperature by $2-4{ }^{\circ} \mathrm{C}$ only with the spraying system.

Table 1

The average data of hydraulic tests of the circulating water cooling system

\begin{tabular}{|c|c|c|c|c|}
\hline \# & Indicator & \multicolumn{3}{|c|}{ Numerical value } \\
\hline 1 & Number of operating main cooling sectors (CS) & 8 & 9 & 12 \\
\hline 2 & Water supply to cooling towers $W, \mathrm{~m}^{3} / \mathrm{hr}$. & 28788 & 28157 & 29849 \\
\hline 3 & Pressure in the discharge pipe of circulating pumps, $\mathrm{kgf} / \mathrm{cm}^{2}$ & 2.481 & 2.465 & 2.45 \\
\hline 4 & $\begin{array}{l}\text { Hydraulic resistance of the section from the circulating pumps } \\
\text { to the ring pipeline of the cooling tower, } \mathrm{kgf} / \mathrm{cm}^{2}\end{array}$ & 0.016 & 0.01 & 0.025 \\
\hline 5 & Pressure at the inlet to the cooling sectors, $\mathrm{kgf} / \mathrm{cm}^{2}$ & 2.73 & 2.73 & 2.68 \\
\hline 6 & $\begin{array}{l}\text { Hydraulic resistance of the section located before of the cooling } \\
\text { sectors, } \mathrm{kgf} / \mathrm{cm}^{2}\end{array}$ & 0.067 & 0.057 & 0.077 \\
\hline 7 & $\begin{array}{l}\text { Pressure in the pipeline at the outlet of the cooling sectors, } \\
\mathrm{kgf} / \mathrm{cm}^{2}\end{array}$ & 2.41 & 2.39 & 2.4 \\
\hline 8 & Hydraulic resistance of cooling sectors, $\mathrm{kgf} / \mathrm{cm}^{2}$ & 0.361 & 0.381 & 0.301 \\
\hline 9 & $\begin{array}{l}\text { Hydraulic resistance of the pipeline section before of the hydro } \\
\text { turbine, } \mathrm{kgf} / \mathrm{cm}^{2}\end{array}$ & 0.344 & 0.314 & 0.144 \\
\hline 10 & Hydraulic resistance of the hydro turbine, $\mathrm{kgf} / \mathrm{cm}^{2}$ & 1.04 & 1.03 & 1.18 \\
\hline 11 & Steam condenser inlet pressure, $\mathrm{kgf} / \mathrm{cm}^{2}$ & -0.34 & -0.33 & -0.29 \\
\hline 12 & $\begin{array}{l}\text { Hydraulic resistance of the pipeline section from the turbine to } \\
\text { the nozzles in the condenser, } \mathrm{kgf} / \mathrm{cm}^{2}\end{array}$ & 0.240 & 0.248 & 0.199 \\
\hline 13 & Pressure at the inlet to the circulation pumps, $\mathrm{kgf} / \mathrm{cm}^{2}$ & -0.13 & -0.14 & -0.16 \\
\hline 14 & $\begin{array}{l}\text { Hydraulic resistance of the suction pipe of circulating pumps, } \\
\mathrm{kgf} / \mathrm{cm}^{2}\end{array}$ & 0.186 & 0.146 & 0.246 \\
\hline
\end{tabular}

The results of hydraulic tests of the circulating water cooling system of the power unit are shown in the Table 1. 
Relative to the axis of the circulating pumps, some structures and equipment of the steam condensing system and circulating water cooling system are located higher by $9.0-17.0 \mathrm{~m}$ and some lower by $7.5 \mathrm{~m}$ (Fig. 2).

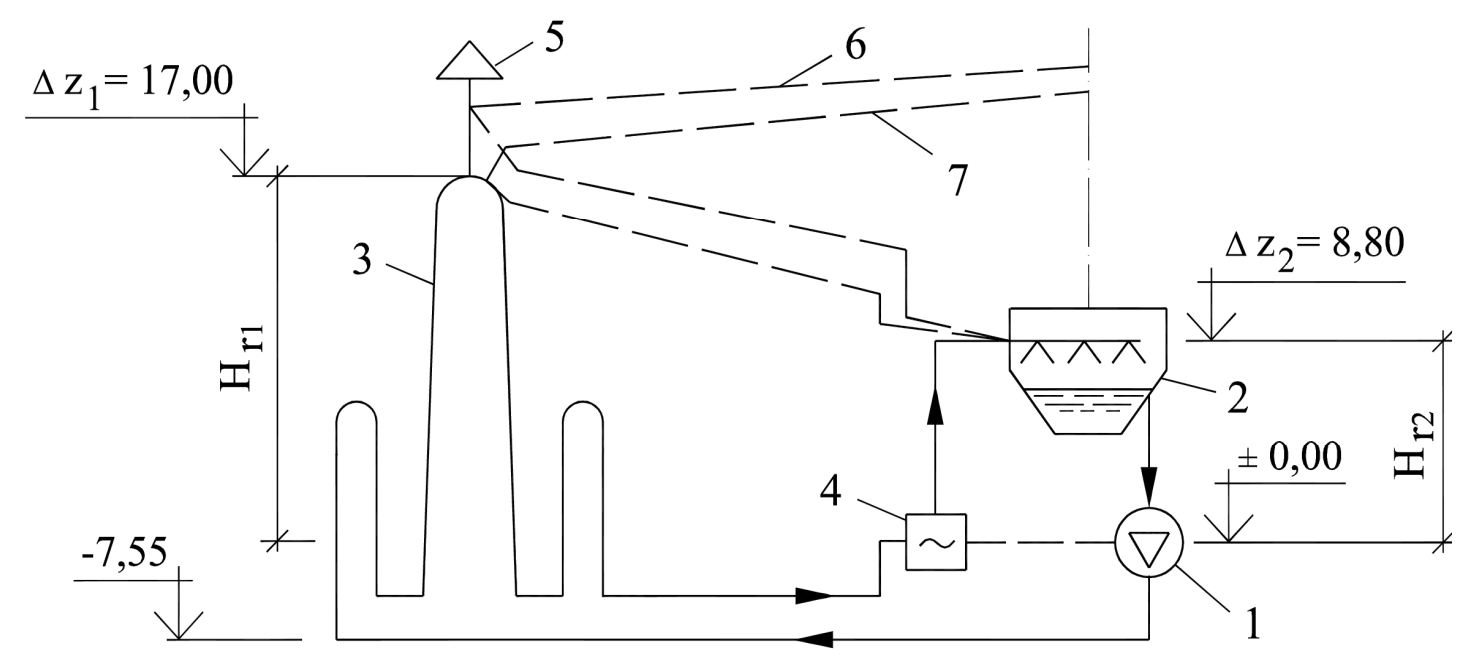

Fig. 2. Scheme for determining the geometric head of circulation pumps: 1 -circulating pump; 2 -turbine steam condenser of the power unit; 3 -cooling sectors of the cooling tower; 4 - hydro turbine; 5 -air outlet pipeline; 6 - piezometric line for the mode of operation when the dictation point for the circulating pump pressure is the top of the cooling sectors; 7 -piezometric line for the mode of operation when the cooling sectors is not connected to the atmosphere

One of the parameters that affect the pressure of circulating pumps is the mark of the upper part of the cooling sectors of the cooling tower (if the circulating water cooling system is connected to the atmosphere by pipeline 5 (Fig. 2)). In this mode of operation, the position of the operating point of the circulating pumps depends on the elevation mark $Z_{1}$ and the hydraulic characteristics of the pipeline section from the circulating pumps to the cooling tower. Under these conditions, the head of the circulation pumps increases, and their flow rate decreases. It is impossible to significantly increase the flow rate of circulation pumps in this operating mode.

The pressure losses determined for different values of water flow rate in the pipeline section from the circulating pumps to the cooling tower were in the ranged from 0.01 to $0.025 \mathrm{kgf} / \mathrm{cm}^{2}$. The circulation pumps flow rate to the cooling system can be increased if the following conditions are met simultaneously:

- the value of hydraulic head losses in the hydro turbine is reduced;

- when the circulating water cooling system is working the cooling sectors are not connected to the atmosphere.

Then the dictating point for the pressure will be the turbine steam condenser. In this case, a small vacuum is possible in the upper parts of the cooling sectors of the cooling tower. Therefore, the structures of the cooling sectors must have a sufficient margin of safety.

The geometric head $H_{g}$ in this mode of operation is the difference between the elevation marks of the piezometric lines (Fig. 2) in the water supply pipeline at the inlet to the steam condenser $Z_{1}$ and $Z_{2}$ at the water inlet to the circulating pumps. Then, taking into account the value of the required pressure for the nozzles, the geometric head can be found as:

$$
H_{g}=\left(Z_{2}+h_{w}-\frac{P_{c o n}}{\rho g}\right)-\left(Z_{3}-\frac{P_{c o n}}{\rho g}\right)=Z_{2}-Z_{3}+h_{w},
$$

where $h_{w}$ - the required pressure for the nozzles in steam condenser, $h_{w}=2.5 \mathrm{~m} ; P_{c o n}-$ steam pressure in the condenser. 
In the $Q-H$ curve of circulation system, the component $h_{w}$ is related to the geometric head $H_{g}$ of the circulation pumps. Its value significantly depends on the steam pressure in the condenser $P_{c o n}$ :

$$
h_{w}=P_{c w}-P_{c o n},
$$

where $P_{c w}$ - the pressure at the inlet to the condenser.

Numerical values of the components of formula (2) according to the results of research paper [Bosak M. et al., Table 1] are as follows: $P_{c w}=62847 \mathrm{~Pa} ; P_{c o n}=9807 \mathrm{~Pa} ; h_{w}=53040 \mathrm{~Pa}=5.43 \mathrm{mH}_{2} \mathrm{O}$. The actual value of the $h_{w}$ even exceeded the calculated design value. However, the supply of cooling water by circulating pumps was lower than the design one by $2000-2500 \mathrm{~m}^{3} / \mathrm{hr}$. This is due to the fact that the water flow rate in the circulation system depends on the position of the operating point on the graph of the hydraulic characteristics of the pump and the entire circulating water cooling system. The spray nozzles are located at the end of the steam condensing system and the circulating water cooling system. The water head losses in them are $(0.15-0.20) h_{w}$, which does not significantly affect the total water head losses and the circulating pumps water flow rate.

The data from Table 1 show that, among other elements of the cooling system, the head losses are the largest in a hydro turbine. To increase the water supply by circulating pumps, it is advisable to reduce the head losses in the turbine by adjusting the guide vane. Let's investigate how the common operating point of circulating pumps and cooling system will change in this case. For calculations, experimental data and theoretical dependences were used. The losses of water head along the length $L$ of the pipeline, for quadratic resistance zone, are determined by the formula:

$$
h_{l}=S_{\Sigma l} \cdot Q^{2},
$$

where $S_{\Sigma l}$ - coefficient of resistance of the circulating water cooling system including local hydraulic resistances; $Q$ - water flow rate.

$$
S_{\Sigma l}=\frac{8 \cdot \lambda \cdot l}{g \pi^{2} d^{5}} .
$$

The hydraulic resistance of the hydro turbine does not depend on the value of $\lambda$, therefore, taking into account the change in the hydraulic resistance of the hydro turbine, the pressure losses in pipelines and other system elements are determined by the formula:

$$
h_{\Sigma l}=S_{\Sigma l} \cdot Q^{2}-\Delta S_{h t} \cdot Q^{2}=Q^{2}\left(S_{\Sigma 1}-\Delta S_{h t}\right),
$$

where $\Delta S_{h t}=\Delta h_{h t} / Q^{2}$ - decrease in the resistance of hydro turbine; $\Delta h_{h t}$ - head loss in the hydro turbine.

The results of the calculations are summarized in Table 2. In numerical values $\sum h_{l}$ and $S_{\Sigma 1}$ the amount of water supplied to the system by pumps type Д 6300-27 is taken into account.

Table 2

Experimental-calculated hydraulic characteristics of the circulating water cooling system

\begin{tabular}{|l|c|c|c|c|c|c|l|}
\hline Operating conditions & $\begin{array}{c}\text { Water flow rate } \\
\text { CP-1+ CP-2 } \\
\mathrm{m}^{3} / \mathrm{hr}\end{array}$ & $\begin{array}{c}\text { Water head } \\
\text { CP-1+CP-2 } \\
\mathrm{kgf} / \mathrm{cm}^{2}\end{array}$ & $\begin{array}{c}\sum \mathrm{h}_{1}, \\
\mathrm{kgf} / \mathrm{cm}^{2}\end{array}$ & $\begin{array}{c}\mathrm{h}_{\mathrm{ht}} \\
\mathrm{kgf} / \mathrm{cm}^{2}\end{array}$ & $\begin{array}{c}S_{\Sigma l}, \\
\mathrm{kgf}{ }^{2} / \\
\left(\mathrm{m}^{5} 10^{4}\right)\end{array}$ & $\begin{array}{c}S_{m 2}, \\
\mathrm{~kg} \cdot \mathrm{s}^{2} / \\
\mathrm{m}^{5} 10^{4}\end{array}$ & $\begin{array}{c}\text { Way of } \\
\text { determining }\end{array}$ \\
\hline CP-1,2; 8 CS: HT-1,2 & 18200 & 2.65 & 2.254 & 1.03 & 0.0882 & 0.040 & Experiment \\
\hline CP-1,2; 9 CS: HT-1,2 & 20000 & 2.62 & 2.186 & 1.04 & 0.085 & 0.047 & Experiment \\
\hline CP-1,2; 12 CS: HT-1,2 & 20700 & 2.61 & 2.172 & 1.18 & 0.0657 & 0.0357 & Experiment \\
\hline CP-1,2; 9 CS: HT-1,2 & 24000 & & 2.30 & 0.52 & 0.0615 & 0.0235 & Calculation \\
\hline CP-1,2; 12 CS: HT-1,2 & 23900 & & 2.08 & 0.30 & 0.051 & 0.014 & Calculation \\
\hline CP-1,2; 12 CS: HT-1,2 & 23200 & 2.37 & 1.87 & 0.15 & 0.045 & 0.007 & Calculation \\
\hline
\end{tabular}


With an increase in the number of operating cooling sectors from eight to twelve, the water pressure loss for circulation pumps decreases by about $0.10 \mathrm{kgf} / \mathrm{cm}^{2}$.

The common graphical characteristics of the cooling system pipelines and operating circulating pumps are shown in Fig. 3. The $Q-H$ curve of the cooling system pipelines takes into account the operation of all pumps.

The hydro turbine, as a part of circulating water cooling system generates the additional electric power using excess water pressure in the pipeline in the section from the cooling tower to the condenser. At the same time, the turbine increases the water pressure losses in the cooling system, which reduces the water supply by circulating pumps. With a decreased in the resistance of the hydro turbine from 1.04 to $0.15 \mathrm{kgf} / \mathrm{cm}^{2}$, the water supply to the turbine steam condenser increased by $3200 \mathrm{~m}^{3} / \mathrm{hr}$ and also increased the power of the turbo generator due to a decreased in steam pressure in the condenser. At the same time, the head of the circulation pumps decreased by $4.2 \mathrm{mH}_{2} \mathrm{O}$. The water pressure in the upper parts of the twenty-meter cooling sectors was in the range of $0.00-0.15 \mathrm{kgf} / \mathrm{cm}^{2}$.

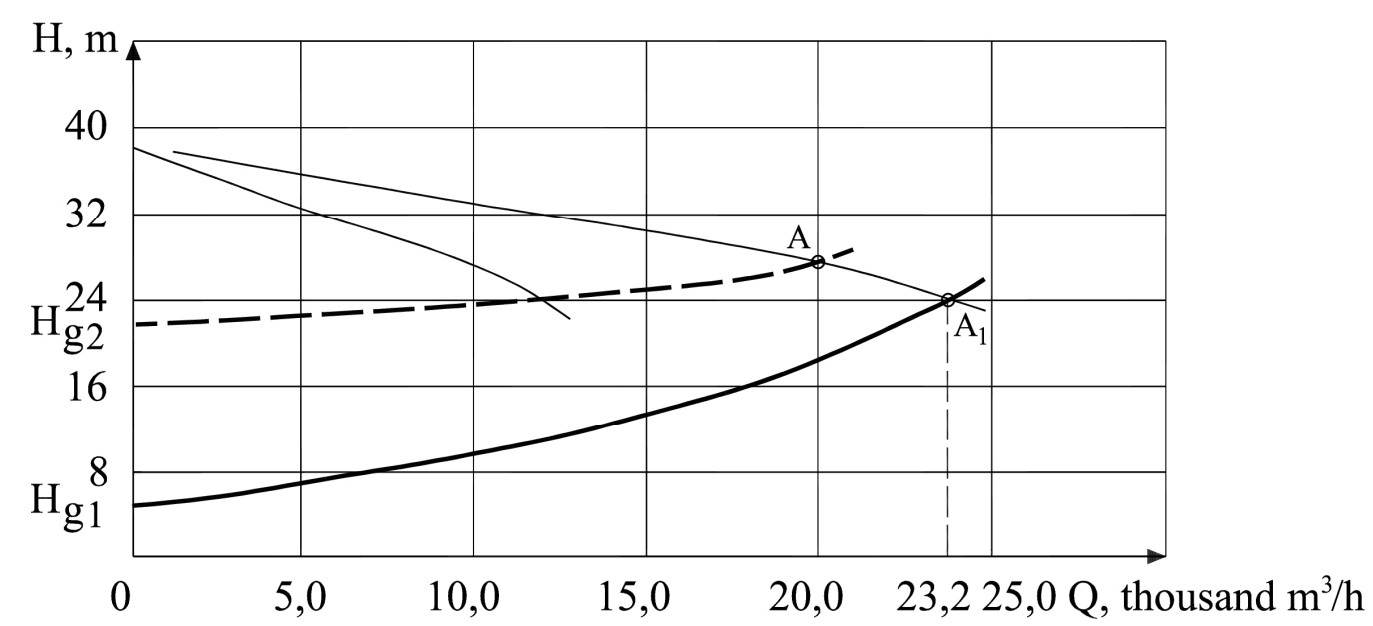

Fig. 3. Characteristics of the cooling system and circulating pumps type Д 12500-24; 1 - experimental, in the mode of operation when the dictating level for the head of the circulating pumps is the top of the cooling sectors of the cooling tower; 2 -calculated, for the operating mode in which the dictating level, for the head of the circulating pumps, is the elevation mark of the distribution pipeline with nozzles in the steam condenser

\section{Conclusions}

1. The circulating pumps of the circulating water cooling system of the power unit can provide the design water supply provided that the hydraulic resistance of the hydro turbine is reduced.

2 . When the cooling tower serves one power unit, the hydraulic characteristics of water supply and water head losses do not change significantly. The temperature of the cooled water decreases by $6.0^{\circ} \mathrm{C}$.

3. The practical and scientific significance of this paper is that its results are useful for the design and operation of similar systems, as well as for educational literature.

Further hydrothermal researches of the circulating water cooling system of the power unit of this type are expedient for experimental confirmation of the predictive calculations given in this scientific paper. In the course of the following researches it is supposed to find out:

- the actual increase in water supply by the circulating pumping station;

- an increase in the power of the turbo generator of the power unit and a decrease in the power of the circulating pumping station turbines due to their regulation;

- operating reliability of the cooling sectors when they are not connected to the atmosphere. 


\section{References}

M. Deziani, .Kh. Rahmani, S. J. Mirrezaei Roudaki \& M. Kordloo, M. (2017) Feasibility study for reduce water evaporative loss in a power plant cooling tower by using air to Air heat exchanger with auxiliary Fan. Desalination Volume 40616, 119-124.

Ali Reza Seifi, Omid AliAkbari, Abdullah A.A.A.Alrashed, FazelAfshary, Gholamreza Ahmadi, Sheikh Shabani, Reza Seifi, Marjan Goodarzi, Farzad Pourfattah (2018) Effects of external wind breakers of Heller dry cooling system in power plants. Applied Thermal Engineering. Volume 129, Pages 1124-1134.

Reza Alizadeh Kheneslu, Ali Jahangiri \& Mohammad Ameri (2020) Interaction effects of natural draft dry cooling tower (NDDCT) performance and 4E (energy, exergy, economic and environmental) analysis of steam power plant under different climatic conditions. Sustainable Energy Technologies and AssessmentsVolume 37, 2020Article 100599.

Guangjun Yang, Li Ding, Tongqing Guo, Xiaoxiao Li Wenxin Tian, Zhen Xu, Zhigang Wang, Furong Sun, JunjieMin, Jingxin Xu, Sheng Wang, Zhaobing Guo. (2020) Study of flue gas emission and improvement measure in a natural draft dry-cooling tower with flue gas injection under unfavorable working conditions. Atmospheric Pollution Research. Volume 11, Issue 5, Pages 963-972.

Peixin Dong, Xiaoxiao Li, Kamel Hooman, Yubiao Sun, \& Hal Gurgenci. (2019) The crosswind effects on the start-up process of natural draft dry cooling towers in dispatchable power plants. International Journal of Heat and Mass Transfer Volume 135, Pages 950-961.

Wenjing Ge, Yuanbin Zhao, Shiwei Song, Wendong Li, Shasha Gao, Tie Feng Chen. (2020) Thermal characteristics of dry cooling tower reconstructed from obsolete natural draft wet coolingtower and the relevant thermal system coupling optimization. Applied Thermal Engineering. Volume 174, 115202.

Z. Nourani, A. Naserbegi, Sh. Tayyebi \& M. Aghaie. (2019) Thermodynamic evaluation of hybrid cooling towers based on ambient temperature. Thermal Science and Engineering ProgressVolume 14, Article 100406.

A. Jahangiri, M. M. Yahyaabadi, \& A. Sharif. (2019) Exergy and economic analysis of using the flue gas injection system of a combined cycle power plant into the Heller Tower to improve the power plant performance. Journal of Cleaner Production, Volume 2331, Pages 695-710.

Peixin Dong, Antonio S. Kaiser, Zhiqiang Guan, Xiaoxiao Li \& Kamel Hooman. (2019) A novel method to predict the transient start-up time for natural draft dry cooling towers in dispatchable power plants. International Journal of Heat and Mass Transfer, Volume 145, Article 118794.

Xiaoxiao Li, Hal Gurgenci, Zhiqiang Guan, Xurong Wang \& Sam Duniam. (2017) Measurements of crosswind influence on a natural draft dry cooling tower for a solar thermal power plant. Applied EnergyVolume 20615 Pages 1169-1183.

Xuehong Chen, Fengzhong Sun, Youliang Chen, MingGao. (2019) Novel method for improving the cooling performance of natural draft wet cooling towers. Applied Thermal Engineering. Volume 147, Pages 562-570.

Zhigang Dang, Ming Gao, Guoqing Long, Jian Zou, Suoying He, Fengzhong Sun. (2019) Crosswind influence on cooling capacity in different zones for high level water collecting wet coolingtowers based on field test. Journal of Wind Engineering and Industrial Aerodynamics. Volume 190, Pages 134-142.

Peixin Dong, Xiaoxiao Li, Zhiqiang Guan, \& Hal Gurgenci. (2018) The transient start-up process of natural draft dry cooling towers in dispatchable thermal power plants. International Journal of Heat and Mass Transfer Volume 123 Pages 201-212.

Bosak M., Cherniuk V., Matlai I., Bihun I. (2019) Studying the mutual interaction of hydraulic characteristics of water distributing pipelines and their spraying devices in the coolers at energy units. Eastern-European Journal of Enterpricse Technologies. Volume 3/8 (99). Pages 23-29. 
М. П. Босак ${ }^{1}$, О. Г. Гвоздецький ${ }^{1}$, Б. С. Піцишин ${ }^{1}$, С. М. Вдовичук ${ }^{2}$

${ }^{1}$ Національний університет “Львівська політехніка”, кафедра гідротехніки та водної інженерії

${ }^{2}$ ПАТ ЛьвівОРГРЕС

\section{ДОСЛДЖЕННЯ СИСТЕМИ ЦИРКУЛЯЦІЙНОГО ВОДОПОСТАЧАННЯ ЕНЕРГОБЛОКУ ТЕПЛОВОЇ ЕЛЕКТРОСТАНЦІї $З$ ГРАДИРНЯМИ ГЕЛЛЕРА}

(C) Босак М. П., Гвоздецьький О. Г., Піичишин Б. С., Вдовичук С. М., 2020

Виконано аналітичні гідравлічні дослідження системи охолодження циркуляційної води (ОЦВ) енергоблоку TEC з градирнею Геллера. Аналітичні дослідження виконані на базі експериментальних даних, отриманих у процесі пускових випробувань системи ОЦВ енергоблоку “Раздан-5” потужністю 300 МВт. Дослідження системи ОЦВ проведені при електричній потужності енергоблоку 200-299 МВт, 3 тепловим навантаженням 320-396 Гкал/год. Основна мета роботи - з'ясувати гідравлічний режим циркуляційної системи охолодження для можливості збільшення подачі води. Величина подачі охолоджувальної води та ії температура впливають на вакуум у конденсаторі турбіни. В кінцевому результаті це впливає на потужність турбогенератора ТЕС Максимальна фактична подача води циркуляційною насосною станцією становила $32000 \mathrm{~m}^{3} /$ год, що нижче проєктної. Циркуляційними насосами (ЦН) вода в суміші з конденсатом подається в градирню, звідки вона вертається через гідротурбіну на розприскування форсунками в конденсаторі пари турбіни. Спроба збільшити подачу води в конденсатор збільшенням отворів форсунок не дала бажаних результатів. Величина подачі води в ЦН залежить від втрати напору в системі ОЦВ. Зі складових системи вони найвищі в гідротурбінах, які $\epsilon$ в складі циркуляційної насосної станції. Тому регулюючи навантаження гідротурбіни, зі зменшенням втрат напору води, можна збільшити подачу води циркуляційними насосами в конденсатор. Для розрахунків зміненої гідравлічної характеристики системи ОЦВ використано експериментальні дані та розроблені теоретичні залежності. В результаті зменшення втрат напору на ділянці гідротурбіни 3 1,04 до 0,15 кгс/см² диктуючою точкою для напору ЦН буде конденсатор пари турбіни. Слід зауважити, що в такому режимі роботи, у верхніх частинах охолоджувальних секторів градирні можливий вакуум. Градирня ТЕС розрахована на обслуговування двох енергоблоків. В умовах теплового навантаження від одного енергоблоку температура охолодженої води, конденсату була нижчою за проєктні значення. Ввімкнення в роботу секторів пікових охолоджувачів градирні дає зниження на $2-4{ }^{\circ} \mathrm{C}$ температури охолодженої води лише з системою зрошення.

Ключові слова: система охолодження циркуляційної води, втрати напору в елементах системи, подача і напір циркуляційних насосів, градирня Геллера. 